\title{
Nitrogen and sulphur management: challenges for organic sources in temperate agricultural systems
}

\author{
A.M. McNeill ${ }^{1, *}$, J. Eriksen ${ }^{2}$, L. Bergström ${ }^{3}$, K.A. Smith ${ }^{4}$, H. Marstorp ${ }^{3}$, \\ H. Kirchmann ${ }^{3} \&$ I. Nilsson ${ }^{3}$
}

\begin{abstract}
A current global trend towards intensification or specialization of agricultural enterprises has been accompanied by increasing public awareness of associated environmental consequences. Air and water pollution from losses of nutrients, such as nitrogen $(\mathrm{N})$ and sulphur $(\mathrm{S})$, are a major concern. Governments have initiated extensive regulatory frameworks, including various land use policies, in an attempt to control or reduce the losses. This paper presents an overview of critical input and loss processes affecting $\mathrm{N}$ and $\mathrm{S}$ for temperate climates, and provides some background to the discussion in subsequent papers evaluating specific farming systems. Management effects on potential gaseous and leaching losses, the lack of synchrony between supply of nutrients and plant demand, and options for optimizing the efficiency of $\mathrm{N}$ and $\mathrm{S}$ use are reviewed. Integration of inorganic and organic fertilizer inputs and the equitable re-distribution of nutrients from manure are discussed. The paper concludes by highlighting a need for innovative research that is also targeted to practical approaches for reducing $\mathrm{N}$ and $\mathrm{S}$ losses, and improving the overall synchrony between supply and demand.
\end{abstract}

Keywords: Animal wastes, manures, excreta, plant residues, biological nitrogen fixation, volatilization, leaching, soil organic matter

\section{INTRODUCTION}

A griculture has undergone drastic changes over the last four to five decades, and farms have increasingly become more specialized and more intensive, with livestock and arable production often being concentrated in different regions of a country. These changes have been accompanied by a greater potential for losses of nutrients, such as nitrogen $(\mathrm{N})$ and sulphur $(\mathrm{S})$, to the environment. Dissolved $\mathrm{N}$ and $\mathrm{S}$ chemical species (mainly $\mathrm{NO}_{3}^{-}$and $\mathrm{SO}_{4}^{2-}$ ) may be leached to surface and/or groundwaters, or lost through gaseous emissions of ammonia, nitrous oxide (from microbial nitrification and denitrification) and volatile organic S compounds such as sulphides. Increased awareness of these environmental effects, coupled with the changes in farm systems, has stimulated extensive governmental frameworks that are attempting to control or reduce the losses through various regulations and land use policies.

\footnotetext{
${ }^{1}$ Soil \& Land Systems, School of Earth \& Environmental Sciences, University of Adelaide, Roseworthy Campus, SA5371, Australia. ${ }^{2}$ Department of Agroecology, Danish Institute of Agricultural Sciences, PO Box 50, 8830 Tjele, Denmark. ${ }^{3}$ Department of Soil Sciences, Swedish University of Agricultural Sciences, Box 7014, SE-75007 Uppsala, Sweden. ${ }^{4}$ Institute of Atmospheric \& Environmental Science, School of GeoSciences, University of Edinburgh, Darwin Bldg, Mayfield Rd, Edinburgh EH9 3JU, UK

*Corresponding author. Fax: +61 883037979

E-mail: ann.mcneill[a]adelaide.edu.au
}

Currently, there is another trend - primarily in North American and European farming systems, but also in China, Latin America and Africa - towards on-farm recycling of animal manures or increased use of organic fertilizers that could lead to more sustainable nutrient management (Stockdale et al. 2001). This shift towards organic farming practices has received political attention in Europe because the general public perceives that these practices reduce environmental problems related to intensive agriculture (National Research Council 1989; Granstedt 1995). As an example, the Swedish parliament has passed a law stating that by the year $2005,20 \%$ of the agricultural land should be under organic farming. However, use of organic fertilizers on a large scale is not without risk. Even with best management practices there are new challenges associated with organic fertilizers, because the risk of losses to water and air is potentially larger, and the use efficiency is lower, compared with the use of equivalent quantities of inorganic fertilizers (Bergström \& Kirchmann 1999).

Nitrogen and sulphur are essential plant nutrients that are often a focus for this nutrient management debate because (i) the anionic forms $\left(\mathrm{NO}_{3}^{-}\right.$and $\left.\mathrm{SO}_{4}^{-2}\right)$ of both are mobile and easily lost from many soils through leaching, and (ii) the overwhelming proportion of both nutrients in the soil is found in an organic form and not immediately available to plants. Therefore, management 
solutions affecting one nutrient will also, potentially, have an effect on the other. Also, over the last few decades, industrial Western societies have reduced atmospheric pollution by replacing high-S coal and oil with low-S natural gas, nuclear energy, and renewable energy sources. These changes in fuels, combined with the use of fertilizers with lower by-product $S$, have resulted in a major reduction in $\mathrm{S}$ deposition and application to the land. The reduced inputs, coupled with cropping system changes that have resulted in growing crops with a greater $\mathrm{S}$ requirement, for example oilseed rape (Brassica napus L.), have thus created a first-time need for $\mathrm{S}$ fertilization in some soils.

The multitude of interactions among agricultural practices (e.g. crop sequence), industrial practices (e.g. fuel sources), and policy decisions (e.g. organic versus inorganic farming systems) means that for increased sustainability it is essential to consider how all factors may be affected before adopting any one solution. In that context, this paper presents quantitative information concerning the key input and loss processes for $\mathrm{N}$ and $\mathrm{S}$ in temperate agricultural systems. The focus is primarily on organic nutrient sources because currently less information is available on those practices than on inorganic ones (Watson et al. 2002). Potential management solutions that can efficiently utilize both inorganic and organic $\mathrm{N}$ and $\mathrm{S}$ sources for crop and pasture production while minimizing losses to the environment are reviewed, although greater detail will be provided in the subsequent papers of this Supplement dealing with overall nutrient management for specific farming systems.

\section{INPUTS AND RECYCLING OF NITROGEN AND SULPHUR}

Atmospheric deposition

Deposition of $\mathrm{N}$ can vary between $5 \mathrm{~kg} \mathrm{Nha}^{-1} \mathrm{yr}^{-1}$ in northern Scandinavia and $45 \mathrm{~kg} \mathrm{ha}^{-1} \mathrm{yr}^{-1}$ in the Benelux countries (Ferm 1998). In Western Europe and other intensively farmed regions, most $\mathrm{N}$ that is deposited has previously been emitted as ammonia $\left(\mathrm{NH}_{3}\right)$ from manure (faeces and urine) of agricultural livestock (ECETOC 1994), or as $\mathrm{NO}_{\mathrm{x}}$ compounds from vehicular traffic and stationary combustion (Dentener \& Crutzen 1994). Emission and deposition of ammoniacal $\mathrm{N}$ in Europe is still considerable, despite measures to reduce $\mathrm{NH}_{3}$ volatilization from agriculture. Such measures include covering slurry and urine storage facilities, rapid incorporation of animal wastes after spreading on bare soil, development of new spreading techniques, and improved handling and ventilation within animal houses (Gustavsson 1998). Furthermore, because all atmospheric $\mathrm{N}$ compounds are watersoluble and easily taken up by organisms, deposition readily leads to eutrophication, acidification and/or damage to sensitive types of vegetation, for example natural ecosystems such as woodland, heathland or grassland, if the critical load is exceeded.

In contrast to high $\mathrm{N}$ deposition, sulphur deficiencies have been reported in previously $\mathrm{S}$-sufficient areas. The main reasons for this include: (i) the environmental control of $\mathrm{SO}_{2}$ emissions in industrial areas and ensuing declines in $\mathrm{S}$ deposition, (ii) the increasing use of $\mathrm{P}$ fertilizers with a low $\mathrm{S}$ content, (iii) the increase in yields obtained as a result of other technological improvements, and (iv) the decreasing use of S-containing pesticides (Blair 2002). In Europe, concentrations of $\mathrm{SO}_{2}$ in the atmosphere have decreased dramatically during the last 20-30 years (Figure 1), leading to decreased deposition of $S$ on agricultural land. Current total $S$ deposition calculated by EMEP (Programme for Monitoring and Evaluating of Long-range Transmission of Air Pollutants in Europe) ranges from $1 \mathrm{kgS} \mathrm{ha}{ }^{-1} \mathrm{yr}^{-1}$ in rural areas of northern Norway to more than $20 \mathrm{~kg} \mathrm{ha}^{-1} \mathrm{yr}^{-1}$ in industrial areas, with an average of $2-10 \mathrm{~kg} \mathrm{Sha}^{-1}$ in many areas (McGrath et al. 2002).

\section{Legume nitrogen fixation}

Inputs of biologically fixed $\mathrm{N}$ to temperate farming systems occur largely via legume-rhizobium symbioses, with relatively insignificant additions from non-symbiotic and

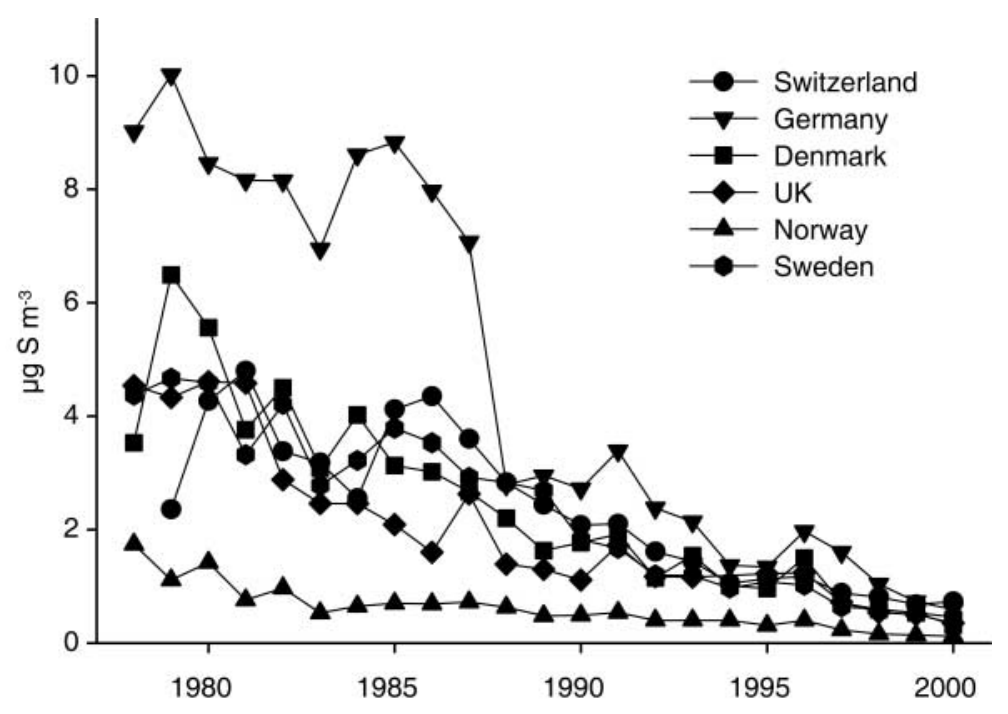

Figure 1. Atmospheric sulphur dioxide concentration at different sites in Europe. (Source: NILU 2003.) 
associative sources (Chalk 1991; Kennedy \& Islam 2001). The potential for $\mathrm{N}$ fixation within temperate farming systems ranges from 200 to $700 \mathrm{~kg} \mathrm{Nha}^{-1} \mathrm{yr}^{-1}$, depending upon the type of legume (Ledgard 2001), although the potential is often not achieved and values as low as $2 \mathrm{~kg} \mathrm{~N} \mathrm{ha}^{-1} \mathrm{yr}^{-1}$ have been reported (Peoples et al. 1995).

Overall, inputs of fixed $\mathrm{N}$ are governed by the productivity of the legume as influenced by management, climatic and edaphic conditions and the dependence of the legume on N fixation (Van Kessel \& Hartley 2000). The latter is primarily determined by the effectiveness of the host legume-rhizobium symbiosis and has been reported to vary widely both within and between legume species (Peoples et al. 1995; Jensen 1997; Unkovich \& Pate 2000; Peoples \& Baldock 2001). Published field data are relatively scarce, particularly for cool temperate regions, but Australian studies suggest that fixation is often lower than the optimum due to absence of suitable rhizobium strains or inhibition of an effective symbiosis by elevated $\mathrm{N}$ fertility status of the soil (Schwenke et al. 1998).

Nitrogen inputs from grain legumes are highly dependent on the crop $\mathrm{N}$ harvest index, that is the proportion of total above-ground $\mathrm{N}$ production removed as grain. Data from temperate Europe and Asia, North America and Australia (Beck et al. 1991; Peoples et al. 1995; Jensen 1997; Van Kessel \& Hartley 2000) show an enormous range in this variable, and it is not surprising that some studies show a positive effect of grain legumes on the soil $\mathrm{N}$ balance (Badaruddin \& Meyer 1994; White et al. 1994; Schwenke et al. 1998), whereas others show a neutral or a negative effect (Beck et al. 1991; Hossain et al. 1996; Armstrong et al. 1997). However, most of these $\mathrm{N}$ balances have probably underestimated the below-ground input of fixed $\mathrm{N}$ by legumes due to problems of root sampling and quantifying root exudates or rhizodeposition (Russell \& Fillery 1996; Jørgensen \& Ledgard 1997; McNeill et al. 1997; Unkovich et al. 1997; Rochester et al. 1998; Papastylianou 1999; Khan et al. 2003; Mayer et al. 2003).

Quantifying inputs of fixed $\mathrm{N}$ by pasture and forage legumes is difficult, owing to the recycling that occurs through the grazing animal and the $\mathrm{N}$ transfer between legume and non-legume species in the system. The fixation is also regulated by a feedback mechanism involving the soil inorganic $\mathrm{N}$ content and competition from associated grasses (Ledgard \& Steele 1992). Field studies report fixation rates from as low as $2 \mathrm{~kg} \mathrm{Nha}^{-1} \mathrm{yr}^{-1}$ up to $315 \mathrm{~kg} \mathrm{~N} \mathrm{ha}^{-1} \mathrm{yr}^{-1}$ (Vinther \& Jensen 2000; Ledgard 2001; Peoples \& Baldock 2001). Clearly, including estimates of fixed $\mathrm{N}$ partitioned below ground (as mentioned previously) would increase the magnitude of these estimates.

Nitrogen fixed by legumes represents a key contribution to nutrient cycling in legume-based farming systems by increasing soil organic $\mathrm{N}$ status, although the process may also contribute to an elevated nitrate leaching potential on certain soil types if not managed effectively.

\section{Plant residues and soil organic matter (SOM)}

The magnitude and timing of $\mathrm{N}$ and $\mathrm{S}$ release from residues, and any subsequent immobilization, are strongly influenced by the efficiency of carbon (C) use by the decomposer population, the demand for $\mathrm{N}$ and $\mathrm{S}$, the chemical nature of the plant residues and a range of soil factors (Kumar \& Goh 2000). For non-leguminous crops, return of residues 'in situ' is not strictly an input but can be considered 'recycling' of nutrients, extracted from, and then returned to, the labile SOM pool (Jenkinson 1990; Parton et al. 1994). Subsequently, the organic $N$ and $\mathrm{S}$ may enter either a more stable organic matter pool or an inorganic (plant-available) pool.

Immature or 'fresh' plant materials, such as those in green manures, primarily contain sulphate (up to $10 \%$ of total $\mathrm{S}$ content) and nitrate (up to $5 \%$ of total $\mathrm{N}$ content) that may be very rapidly released and available for plant uptake (Whitehead 2000). These 'fresh' or green residues tend to decompose rapidly, with up to $40 \%$ of residue mineralized after one year. Mature residues decompose more slowly than 'fresh' residues because of a wider C/N ratio and greater lignin/ $\mathrm{N}$ or polyphenol/ $\mathrm{N}$ ratios. The impact of these differences in residue decomposition rates on $\mathrm{N}$ and $\mathrm{S}$ cycling is that $10-20 \%$ of $\mathrm{N}$ in green residues will typically be utilized by the immediate or succeeding crop, whereas $<10 \%$ of the $\mathrm{N}$ in mature residues is taken up (Fillery 2001 and references therein). The primary sink for most of the $\mathrm{N}$ in legume residues is the SOM pool; nevertheless, research has clearly highlighted that $\mathrm{N}$ released from legume residues needs to be synchronized with the demand for $\mathrm{N}$ by the following crop (Myers et al. $1994,1997)$ in order to prevent substantial leaching losses of legume-derived nitrate under wet temperate conditions (see later section on loss processes) or after fallow periods.

\section{Animal manures}

On a dry matter basis, $\mathrm{N}$ and $\mathrm{S}$ concentrations in animal wastes amount to $1.9-10 \% \mathrm{~N}$ (mean: $3.2 \% \mathrm{~N}$ ) and $0.6-$ 0.7\% S (Kirchmann \& Witter 1992; Steineck et al. 1999). This is equivalent to $70-80 \%$ of the amount present in fodder. The $\mathrm{N}$ and $\mathrm{S}$ contents of stored manures can vary, as often they are mixtures of excreta of different age from animals fed different diets, and possibly come from different animal species. Slurries may contain 2.8$5.1 \mathrm{~kg} \mathrm{~N} \mathrm{~m}^{-3}$ and $0.15-0.7 \mathrm{~kg} \mathrm{~S} \mathrm{~m}^{-3}$ (Eriksen et al. 1995), and manures $4.8-7.7 \mathrm{~kg} \mathrm{~N} \mathrm{t}^{-1}$ and $0.69-1.4 \mathrm{~kg} \mathrm{~S} \mathrm{t}^{-1}$ wet weight (Steineck et al. 1999). On a global scale, S excretion from farm animals is estimated to be around 8 million metric tonnes per year, corresponding to $80 \%$ of the world consumption of mineral S fertilizer (Eriksen 2002).

The conversion of dietary $\mathrm{N}$ into animal protein typically ranges from 5 to $20 \%$ and is generally lower for legumes than grasses (Ulyatt et al. 1988). Balancing the supply of $\mathrm{N}$ in animal diets can be easily achieved by using legumes or well-fertilized non-legumes as fodder, but the intake of $\mathrm{S}$ by animals may often be limited by a low $\mathrm{S}$ content of the fodder. For example, in diets for monogastrics where cereal grains constitute the main source of protein, methionine is often one of the most limiting essential amino acids (Heger et al. 1997). Also, cattle diets in areas with low $S$ deposition may be short of $S$ (Aaes \& Thøgersen 1999). Under such conditions, the $S$ content of the manure will be relatively low and mainly in the organic form, which is not readily available to crops after soil 
application. Furthermore, more efficient fodder utilization may also affect amounts of $\mathrm{N}$ and $\mathrm{S}$ excreted per unit of animal or milk produced, which may affect the composition of animal wastes. A greater portion of $\mathrm{N}$ and $\mathrm{S}$ will probably be present in organic forms in animal wastes and less will be present in urine (Kyvsgaard et al. 2000).

Annual application of manure will increase the soil organic $\mathrm{N}$ and $\mathrm{S}$ content in the long term, although the extent of this increase depends on soil type, cropping system and management. Manure applications may also increase the potential mineralization rate. Therefore, a residual effect of long-term organic manure application on the capacity of the system to supply plant-available $\mathrm{N}$ should be expected, although there is no evidence that either organic $\mathrm{N}$ or organic $\mathrm{S}$ in manure will mineralize more readily than the bulk of soil organic $\mathrm{N}$ or $\mathrm{S}$. The ability of a cropping system to utilize mineralized $\mathrm{N}$ and $\mathrm{S}$ will depend on the length of the growing season, although (as mentioned in the previous section) mineralization is unlikely to fully match crop demand.

\section{LOSS PROCESSES FOR NITROGEN AND SULPHUR}

\section{Volatilization}

Manure may be deposited by grazing livestock directly on to pastures, or spread on the land surface as solid farmyard manure (FYM) or liquid slurry, and often can correspond to an annual application rate of several hundred kilograms of $\mathrm{N}$ per hectare. Following excreta deposition or manure spreading, the fraction of $\mathrm{N}$ lost depends on several environmental and edaphic factors. The rates of hydrolysis of urea and dissociation of $\mathrm{NH}_{4}^{+}$to dissolved $\mathrm{NH}_{3}$ and $\mathrm{H}^{+}$ are both temperature-dependent, as is the rate of diffusion of dissolved $\mathrm{NH}_{3}$ to the interface with the atmosphere. This means that the rate of emission of $\mathrm{NH}_{3}$ to the atmosphere increases substantially as the ambient temperature increases. Other factors include: the micrometeorological conditions affecting the rate of transfer of ammonia from the land surface into the atmosphere; the depth of application; within the soil; the initial $\mathrm{pH}$ (losses are inevitably greater in soils that are already alkaline); the buffer capacity of the soil; and the soil water content (e.g. Yan et al. 2003).

Ammonia emissions from land-spreading of solid, strawbased FYM from cattle and pig housings can be of the order of two-thirds of the total ammoniacal nitrogen (TAN) content (Chambers et al. 1997; Menzi et al. 1997; Misselbrook et al. 2000). Similar losses from liquid slurries spread on the soil surface have been reported (Huijsmans et al. 1997; Misselbrook et al. 2000). Ammonia losses increase with increasing dry matter (DM) content of the slurry (Jarvis \& Pain 1990; Sommer \& Olesen 1991), within a range of $1-9 \%$ DM for applications in the autumnspring period (Smith \& Chambers 1995). The emissions from ammoniacal and uric acid $\mathrm{N}$ in poultry manures are substantially lower than those from cattle and pig manures (Chambers et al. 1997; Menzi et al. 1997).

During storage of animal wastes in slurry tanks, urine pits and solid manure heaps or piles, anaerobic microbial processes dominate, whereas aerobic decomposition prevails only in well-aerated composts and deep litter. Formation of volatile ammonia or ammonium from organically bound $\mathrm{N}$ is a main change during anaerobic storage (Kirchmann \& Witter 1989). Similarly, S present as $\mathrm{SO}_{4}^{2-}$ can be reduced and gaseous $\mathrm{S}$ compounds formed under anaerobic storage conditions. These compounds, such as carbon disulphide $\left(\mathrm{CS}_{2}\right)$, carbonyl sulphide (COS), dimethyl sulphide $\left(\mathrm{CH}_{3} \mathrm{SCH}_{3}\right)$, dimethyl disulphide $\left(\mathrm{CH}_{3} \mathrm{SSCH}_{3}\right)$ and methyl mercaptan $\left(\mathrm{CH}_{3} \mathrm{SH}\right)$, as well as hydrogen sulphide $\left(\mathrm{H}_{2} \mathrm{~S}\right)$, can be lost through volatilization (Banwart \& Bremner 1975). However, Beard \& Guenzi (1983) reported minimal loss of $\mathrm{S}$ by volatilization from stored slurries where redox conditions were controlled. Another study by Eriksen et al. (1995) reported a decrease in the total $\mathrm{SO}_{4}^{2-}$ concentration (organic ester sulphates and $\mathrm{SO}_{4}^{2-}$ ) and an increase in sulphide and C-bonded $\mathrm{S}$ in both cattle and pig slurry during storage from February to November. Therefore, as a consequence of storage, different slurries may be expected to have different levels of plant-available $S$ and $\mathrm{N}$.

The anaerobic conditions that are sometimes induced during application of large amounts of manures to fields can also result in production of volatile sulphides (mainly $\mathrm{H}_{2} \mathrm{~S}$ ). However, these sulphides generally react with soil constituents such as $\mathrm{Fe}$ oxides to form $\mathrm{FeS}_{2}$ or $\mathrm{FeS}$ (Metson 1979), which often results in no volatilization of $\mathrm{H}_{2} \mathrm{~S}$ from soils (Freney 1986), except when waterlogging is complete and prolonged, and trace amounts of carbon disulphide or dimethyl sulphide produced by microorganisms may volatilize (Farwell et al. 1979; Brown 1982). Janzen \& Ellert (1998) found emissions of $S$ from soil to have a mean rate of less than $0.2 \mathrm{kgSha}^{-1} \mathrm{yr}^{-1}$ and from plants $0.1-3 \mathrm{~kg} \mathrm{Sha}^{-1} \mathrm{yr}^{-1}$.

\section{Denitrification}

Microbial denitrification - the anaerobic reduction of nitrate present in the soil to gaseous nitrous oxide $\left(\mathrm{N}_{2} \mathrm{O}\right)$, nitric oxide (NO) and dinitrogen $\left(\mathrm{N}_{2}\right)$ - is the main process by which chemically or biologically fixed $\mathrm{N}$ is returned to the atmosphere. Estimates of the quantities of $\mathrm{N}$ lost by the denitrification mechanism from agricultural soils have varied widely. Hauck (1986) suggested losses of $20-40 \%$ of the $\mathrm{N}$ applied, whereas Nieder et al. (1989) gave figures for cropland ranging from $2.5 \%$ to more than $50 \%$.

Nitrate is the principal substrate for denitrification, and thus is a key driving variable (Weier et al. 1993), since low concentrations of $\mathrm{NO}_{3}^{-}$constrain denitrification rates. The soil water content (more particularly the water-filled pore space [WFPS] with its effect on soil aeration) is another major controlling factor. Diffusion of oxygen throughout the soil matrix is usually sufficient to prevent substantial rates of denitrification in soils with plenty of macropores, for example, in coarse sandy soils and in finer textured ones with good structure. However, where there is poor structure - with larger peds rather than small crumbs being common, or loss of air-filled macropores as a result of compaction by wheels, tillage machinery, or livestock hooves - the outcome is likely to be the development of anaerobic zones within some of the soil structural units, 
and an enhancement of denitrification (e.g. Nieder et al. 1989; Arah et al. 1991).

Soils with greater amounts of labile organic matter will respire faster than those with less, and thus the former have a greater potential for denitrification than the latter (Bijay-Singh et al. 1988). Webster \& Goulding (1989) showed that plots with high $\mathrm{C}$ content, as a result of receiving large inputs of FYM over many years, showed much higher denitrification rates in the autumn than adjacent plots that had received only mineral fertilizers.

Recorded rates of denitrification are relatively few, because of the experimental difficulty associated with making quantitative measurements, but even so, values up to some hundreds (and, occasionally thousands) of grams of $\mathrm{N}$ per hectare per day have been reported (Arah et al. 1991; Weier et al. 1993). Losses exacerbated by the addition of plant residues have been identified in some studies. For example, on a clay loam soil in Scotland where plots were ploughed and sown to grass in July with an addition of $64 \mathrm{~kg} \mathrm{~N}^{-1}$ as $\mathrm{Ca}\left(\mathrm{NO}_{3}\right)_{2}$, about $18 \mathrm{~kg} \mathrm{~N}^{-1}$ were denitrified from the plots without residues, and twice that amount from those with residues (Vinten et al. 1996). There is other evidence that $\mathrm{N}$-rich crop residues may stimulate rapid denitrification and associated nitrous oxide emissions, even in coarse-textured soil. For example, Velthof et al. (2002) reported that $\mathrm{N}_{2} \mathrm{O}$ emissions range up to $14.6 \%$ of the $\mathrm{N}$ added as brassica and sugar beet residues, whereas emissions after adding cereal residues were not significantly different from the control. Similarly, Baggs et al. (2000) found that more than $1 \mathrm{~kg} \mathrm{~N}_{2} \mathrm{O}-\mathrm{N} \mathrm{ha}^{-1}$ was released from a freely drained loamy sand over the first 14 days after incorporation of lettuce (Lactuca sativa L.) residues.

\section{Leaching}

Leaching of inorganic $\mathrm{N}$ as nitrate $\left(\mathrm{NO}_{3}^{-}\right)$, either applied as a fertilizer or derived from mineralization of organic matter inputs, is affected by climate, soil type, geo-hydrological conditions, crop species, timing and rate of fertilizer inputs, and soil management. Generally, $\mathrm{NO}_{3}^{-}$leaching increases as the input of $\mathrm{NO}_{3}^{-}-\mathrm{N}$ increases, although the increase in leaching is usually not continuous but follows a linear split-line relationship with a distinct break-point (e.g. Bergström \& Brink 1986; Lord \& Mitchell 1998). From zero $\mathrm{NO}_{3}^{-}-\mathrm{N}$ addition up to optimum application rates, the increase in $\mathrm{NO}_{3}^{-}$leaching is minimal, whereas at higher rates leaching often increases considerably.

Lord \& Mitchell (1998) showed that as long as crop removal of $\mathrm{N}$ was $52 \%$ of that applied to cereal crops, which is the normal efficiency at economic optimum conditions, leaching was hardly affected at all by the $\mathrm{NO}_{3}^{-}-\mathrm{N}$ input. However, because of the uncertainty involved in predicting the break-point, it was concluded that a small reduction in $\mathrm{N}$ input below the expected economic optimum rate is desirable to considerably reduce the risk of high N-leaching losses. Another strategy is to use multiple, small fertilizer- $\mathrm{N}$ applications, although the long-term effects of differentiated $\mathrm{N}$ applications are still relatively unknown.

Application of large amounts of manure on agricultural fields certainly increases the risk of high N-leaching loads, particularly where drainage is an important component of the water balance. Even relatively modest application rates of manure $\mathrm{N}$ (e.g. $110 \mathrm{~kg} \mathrm{NH}_{4}^{+}-\mathrm{N} \mathrm{ha}^{-1}$ ) can result in N-leaching loads that are higher than if corresponding amounts of inorganic $\mathrm{N}$ fertilizers are used (Kemppainen 1995; Thomsen et al. 1997), particularly where mineralization and plant uptake are not synchronized. For example, in a study where an equal amount of $\mathrm{N}$ as manure or inorganic fertilizer $\left(100 \mathrm{~kg} \mathrm{ha}^{-1}\right)$ was applied to barley, leaching of $\mathrm{N}$ originating from manure was almost ten times higher than that of fertilizer N (Bergström \& Kirchmann 1999). However, given best practice management in both cases, leaching loss under an organic system was reported as similar to, or slightly smaller than, that from a conventional system (Stopes et al. 2002).

Total $\mathrm{N}$ leaching losses in grazed systems vary, ranging from relatively small amounts $\left(6-34 \mathrm{~kg} \mathrm{Nha}^{-1}\right)$ on sheepgrazed temperate grass/clover pastures (Cuttle et al. 1998) to larger amounts $\left(20-74 \mathrm{~kg} \mathrm{Nha}^{-1}\right)$ reported for intensively grazed dairy cattle pastures (Ledgard et al. 1999). In one study, about $55 \%$ of the leached $\mathrm{N}$ was derived from the urine patches (Ruz-Jerez et al. 1995), probably because deposition of $\mathrm{N}$ in urine patches by grazing animals generally exceeds the capacity of the plants to utilize the inorganic $\mathrm{N}$ produced, particularly $\mathrm{NO}_{3}^{-}$(Ball \& Ryden 1984; Haynes \& Williams 1993). Reports of the contribution of legume-fixed $\mathrm{N}$ to leaching losses also range widely from 8 to $80 \%$ (Anderson et al. 1998a, b; Ledgard et al. 1999; Ridley et al. 2001).

Evidence suggests that excess $\mathrm{S}$ inputs from atmospheric deposition in the past were leached as $\mathrm{SO}_{4}^{2-}$ (Eriksen 1996; Knights et al. 2000), particularly on certain soil types. The retention of $\mathrm{SO}_{4}^{2-}$ in soils depends on the nature of the charged mineral surfaces, the $\mathrm{pH}$, and concentrations of $\mathrm{SO}_{4}^{2-}$ and other ions in the soil solution (Harward \& Reisenauer 1966); furthermore, above $\mathrm{pH} 6$ virtually all soil $\mathrm{SO}_{4}^{2-}$ is found in solution (Curtin \& Syers 1990). Even in soils with mineralogy conducive to a high $\mathrm{SO}_{4}^{2-}$ retention capacity, the retention is weak at high $\mathrm{pH}$, and $\mathrm{SO}_{4}^{2-}$ can be removed by repeated extractions with water (Chao et al. 1962). As a consequence, many agricultural soils are prone to $\mathrm{SO}_{4}^{2-}$ leaching, and the amount of leached $\mathrm{SO}_{4}^{2-}$ is closely related to the drainage volume (Shepherd \& Bennett 1998; Eriksen \& Askegaard 2000).

In a dairy crop rotation on a sandy soil, the average $\mathrm{SO}_{4}^{2-}$ leaching from the crop rotation was $20 \mathrm{~kg} \mathrm{Sha}^{-1}$ $\mathrm{yr}^{-1}$, equivalent to $60 \%$ of the total input to the rotation (Eriksen \& Askegaard 2000). Sulphate leaching was very variable, ranging from 4 to $45 \mathrm{~kg} \mathrm{Sha}^{-1} \mathrm{yr}^{-1}$ for the same crop in different years. In a long-term field experiment on a clay loam in south-central Sweden, the average leaching during 35 years in plots treated with $\mathrm{Ca}\left(\mathrm{NO}_{3}\right)_{2}$, green manure and animal manure was estimated to be 24,34 and $38 \mathrm{~kg} \mathrm{~S} \mathrm{ha}^{-1} \mathrm{yr}^{-1}$, respectively, which corresponded to 65 , 71 and $69 \%$ of the $S$ inputs (Kirchmann et al. 1996). Obviously, reliable estimates of $\mathrm{SO}_{4}^{2-}$ leaching will be required when mass balances are used for determining the $\mathrm{S}$ status at field or farm level. This is especially important for temperate regions with a high winter rainfall and soils with a low $\mathrm{SO}_{4}^{2-}$ retention capacity. 


\section{OPTIMIZING USE EFFICIENCY OF NITROGEN AND SULPHUR}

This section focuses on potential management options to improve the management of $\mathrm{N}$ and $\mathrm{S}$ in agricultural systems by optimizing inputs from legume $\mathrm{N}$ fixation, plant residues and animal wastes, while minimizing losses via volatilization, denitrification and leaching. Central to these management strategies is recognition of the lack of synchrony between nutrient release from organic sources and crop demand in current farming systems, and thus the potential requirement for integration of organic and inorganic fertilizer inputs. The concept of equitable re-distribution of nutrients from manure is also discussed.

\section{Inputs from legume nitrogen fixation and plant residues}

Management practices that can optimize inputs from legume $\mathrm{N}$ fixation include maximizing plant growth by providing adequate nutrition, especially $P$, ensuring the presence of an effective rhizobium strain, and minimizing pests and diseases. Also, in a rotation, sowing the legumes into soils with low inorganic $\mathrm{N}$ status can increase $\mathrm{N}$ fixation. Manipulating the mixture of non-legume and legume species within a pasture, for example by using appropriate grazing strategies, can also enhance legume $\mathrm{N}$ fixation.

Transfer of fixed $\mathrm{N}$ within a single season from legume to non-legume via rhizodeposition is recognized around the world as a vitally important component of nutrient cycling in low-input temperate pasture systems (Boller \& Nösberger 1987; Ledgard \& Steele 1992). Controlled environment studies have demonstrated that as much as $15 \%$ of total plant $\mathrm{N}$ in ryegrass can originate from $\mathrm{N}$ exuded from companion white clover (Paynel et al. 2001). Long-term studies in the field have produced results of a similar order of magnitude for older pasture plants (Soussana \& Hartwig 1996; Høgh-Jensen \& Schjoerring 2001), as well as for some grain legumes (Sawatsky \& Soper 1991; Jensen 1996c), with substantial uptake by companion non-legume crop species (Jensen 1996a). The significance of transfer of fixed $\mathrm{N}$ under field conditions within a season, for temperate inter-cropping systems, has yet to be clearly defined; reports from the limited data available are mixed (Danso et al. 1987; Papastylianou 1988; Cowell et al. 1989; Izaurralde et al. 1992; Waterer et al. 1994; Jensen 1996b). Overall, the amount of transfer will, of course, depend on plant species and plant age, as well as on the abiotic and biotic environment (Fujita et al. 1992). It will also be influenced by defoliation (grazing or cutting), although quantifying the effects of such management practices on $\mathrm{N}$ transfer has proved difficult and further research is required (Ledgard 2001).

The asynchrony in supply and demand for $\mathrm{N}$ and $\mathrm{S}$ in organic systems is a major concern and may not be recognized by policy-makers advocating increased adoption of those practices. Current research has focused on manipulating residue quality and quantity, including additions of onfarm and off-farm waste products, to manage nutrient supply and availability to crops. The time course of net $\mathrm{N}$ mineralization has been affected by manipulation of the residue $\mathrm{C} / \mathrm{N}$ ratio, or the phenol content, but also by varying types and concentrations of carbohydrates (e.g. Handayanto et al. 1997; Gunnarsson \& Marstorp 2002; Rahn et al. 2003; De Neve et al. 2004). These practices are particularly critical for areas where leaching is likely (see section below on leaching). However, most approaches, while reducing the high $\mathrm{N}$ release, also reduced the total amount of available $\mathrm{N}$ in the long term (Handayanto et al. 1997). There is clearly a need to identify practices that both improve synchrony and can be adopted by farmers (Myers et al. 1997). In drier climates, this may include management strategies that ensure rapid root development and thus crop $\mathrm{N}$ uptake in response to the onset of rains. Other suggestions for exploiting resource capture include relay cropping with deep-rooted cover crop species (Giller et al. 1997), intercropping (Watson et al. 2002) and selection of crop varieties or types that are efficient in utilizing available nutrients (Foulkes et al. 1998, Le Gouis et al. 2000).

\section{Managing nitrogen in animal pastes}

As mentioned earlier, volatilization of $\mathrm{NH}_{3}$ from animal wastes can occur during housing, storage, application to soil, or grazing (Bussink \& Oenema 1998). Measures to minimize losses of $\mathrm{NH}_{3}$ should lead to an improved utilization of manure $\mathrm{N}$, but all parts of the manure handling chain need to be considered, since intervening in one part affects losses in another. For example, losses are more likely during aerobic storage of manures (composting) than after subsequent soil application, because the remaining $\mathrm{N}$ is mainly in organically bound $\mathrm{N}$ forms $(>90 \%)$ and thus concentrations of inorganic $\mathrm{N}$ are very low (Kirchmann 1985). On the other hand, following anaerobic storage a significant part of the manure $\mathrm{N}$ is present as $\mathrm{NH}_{4}^{+}$and there is a potential for large gaseous losses when the manure is applied to soil. Kirchmann \& Lundwall (1998) concluded that anaerobic waste management, which is standard agricultural practice in Europe, resulted in smaller ammonia losses overall than aerobic treatment. They reported a minimum of $10-15 \%$ of the total $\mathrm{N}$ present lost from the former, but at least $20 \%$ and up to $70 \%$ from the latter.

A major reduction in gaseous emissions from anaerobic wastes can be achieved by replacing simple surface-spreading techniques by other procedures, such as narrow-band application to the soil surface or shallow injection into open or closed slots (Huijsmans et al. 1997; Lorenz \& Steffens 1997). Huijsmans et al. (2001) found that, on average, narrow-band application reduced emissions by $74 \%$ compared with those following surface spreading, and injection reduced them by $92 \%$ (Table 1 ). However, Pain \& Misselbrook (1997) reported much smaller reductions in the UK.

Table 1. Cumulative $\mathrm{NH}_{3}$ losses over $96 \mathrm{~h}$ after application of slurry to grassland by different methods. (Based on data of Huijsmans et al. 2001.)

\begin{tabular}{lrr}
\hline Application method & \multicolumn{2}{c}{$\mathrm{NH}_{3}$ losses } \\
& \multicolumn{2}{c}{$\%$ of $\mathrm{NH}_{4}-\mathrm{N}$ applied $)$} \\
\cline { 2 - 3 } & Range & Mean \\
\hline Surface spreading & $27-98$ & 77 \\
Narrow band spreading & $8-50$ & 20 \\
Shallow injection & $1-25$ & 6 \\
\hline
\end{tabular}


Apart from these issues of $\mathrm{N}$ conservation during storage, handling and application of manure, the ultimate availability of the $\mathrm{N}$ for plant uptake is also important. This will clearly be a function of chemical composition. Inorganic $\mathrm{N}$ in anaerobic manure has been shown to be equally as plant-available as $\mathrm{N}$ from inorganic fertilizer, if the materials are applied at the same time of the year (Kirchmann 1989). Fatty acids present in anaerobic manures can cause a short-term, initial immobilization of $\mathrm{N}$, but this does not seem to affect $\mathrm{N}$ utilization over a growing season (Kirchmann \& Lundvall 1993). In contrast, organic $\mathrm{N}$ in aerobically stabilized manures is only available to crops after net $\mathrm{N}$ mineralization, which is not necessarily synchronized with plant demand (Myers et al. 1997). Thus, inorganic $\mathrm{N}$ derived from organic sources may potentially be lost via leaching or denitrification.

A more fundamental approach towards reducing ammonia emissions from livestock systems is to decrease $\mathrm{N}$ inputs, as opposed to dealing with the N-rich manure after it is produced. Hilhorst et al. (2001) showed that very high $\mathrm{N}$ utilization efficiencies in animal nutrition and crop production permitted a similar milk production to that of conventional intensive dairy farms, but at a much lower input level, while achieving a reduction in the annual $\mathrm{NH}_{3}$ emission from $64 \mathrm{~kg} \mathrm{NH}_{3}-\mathrm{Nha}^{-1}$ on the average farm to only $20 \mathrm{~kg} \mathrm{NH}_{3}-\mathrm{Nha}^{-1}$. Ledgard (2001) discussed the potential for improving $\mathrm{N}$ utilization by grazing animals and highlighted the need for more innovative approaches, such as dietary manipulation involving certain fodder species or supplements that alter the ratio of dung to urine in the excreta and thus reduce the potential for losses.

\section{Management options to reduce nitrogen leaching}

Preventing N leaching is most critical in areas with lighttextured soils, in cold and humid climates and where geohydrological conditions allow for deep percolation of infiltrating water. In these regions, it is obvious that manures applied to bare soil in autumn pose a higher risk for leaching than when they are applied in spring. In particular, early applications immediately following harvest can increase $\mathrm{N}$ leaching several-fold compared with early winter/spring applications (Beckwith et al. 1998). The application rate of manure on individual fields, which will determine the risk for leaching, depends largely on the number of animal units on each farm. In Sweden, there are regulations limiting the stocking rate to 1.6 large livestock units per hectare, based on annual $\mathrm{P}$ removal by crops. However, preliminary estimates based on the above-mentioned study by Bergström \& Kirchmann (1999) indicated that this number had to be lowered to 0.2 in order to reduce $\mathrm{N}$ leaching to the level obtained when $100 \mathrm{~kg} \mathrm{~N} \mathrm{ha}^{-1}$ of inorganic $\mathrm{N}$ fertilizer was used. In Denmark, the number of livestock units is not regulated, but the total application of manure $\mathrm{N}$ and fertilizer $\mathrm{N}$ on each field is controlled instead.

In cold, humid regions, the problems associated with manures are caused by the fact that inorganic $\mathrm{N}$ is often released too late in the season, or after the growing season, and is therefore available for leaching. One solution to reduce this asynchrony between demand and supply of $\mathrm{N}$ is to modify the composition of the organic materials that are applied on fields. This can be achieved by adding organic materials with a high $\mathrm{C} / \mathrm{N}$ ratio (e.g. paper-mill waste; Kirchmann \& Bergström 2003) to the animal manures when they are incorporated into soil. Such practices lead to increased $\mathrm{N}$ immobilization during periods when the risk for $\mathrm{N}$ losses is high.

In recent years, cover crops or 'catch crops', have proven to be effective in reducing $\mathrm{N}$ leaching when grown in conjunction with crops that require high levels of $\mathrm{N}$, such as maize (Zea mays L.) and other cereal grains (see reviews by Meisinger et al. 1991 and Aronsson 2000). The cover crop can take up substantial amounts of $\mathrm{N}$ after harvest of the main crop in autumn, and several studies around the world have demonstrated large consequent reductions in N leaching (Martinez \& Guiraud 1990; Nygaard Sørensen 1991; Shepherd 1999; Bergström \& Jokela 2001), in some cases by greater than $80 \%$ (Lewan 1994). However, there are still uncertainties on how decomposition and mineralization of cover crop residues that are incorporated into soil will affect leaching of $\mathrm{N}$ over the long term. Some will be mineralized very soon after incorporation and some will form quite stable fractions and enter the soil humus pool. Especially when growing cover crops repeatedly, this increase in humus may contribute to larger $\mathrm{N}$ leaching losses over the long term, even though the short-term effect is favourable. Nevertheless, there is reason to believe that cover crops will be used in the future to reduce $\mathrm{N}$ leaching effectively.

The tremendous spatial variability in soil properties and environmental conditions in a region needs to be taken into account when considering countermeasures for reducing $\mathrm{N}$ leaching (e.g. cover crops, minimum tillage). Thus, practices can be targeted to the most sensitive areas, and these may range from catchments to sub-catchments, whole farms to individual fields, and even parts of fields.

\section{Management options for sulphur}

Although the organic $S$ fraction of soil and added manures may be important for the supply of $S$ to plants in deficiency situations, it is often found that mineralization of soil organic $\mathrm{S}$ cannot supply the required amount (Eriksen et al. 1998; Scherer 2001). Lloyd (1994) found a relative use efficiency of $\mathrm{S}$ in cattle slurry of $55 \%$ compared to gypsum $\left(\mathrm{CaSO}_{4} \cdot 2 \mathrm{H}_{2} \mathrm{O}\right)$ when applied to grass intended for silage. However, this was much higher than the relative use efficiency of $5 \%$ found by Eriksen et al. (1995) when applying slurry to spring oilseed rape in a pot experiment. Application of mineral S fertilizer dramatically increased seed yield and $S$ uptake of oilseed rape. In contrast, application rates equivalent to 25 and 50 tonnes of slurry per hectare did not have any effect on seed yield and only slightly increased the $S$ uptake. So if crop yields and quality are to be maintained at present levels, the reductions in atmospheric deposition of $S$ have to be partly replaced by use of inorganic $S$ fertilizers. Indeed, Zhao et al. (2002) reviewed crop responses to $S$ fertilization in Europe and concluded that $S$ is now one of the most limiting nutrients for agricultural production in many European countries. 
Soils most likely to show a sulphur response are free draining sandy soils with low organic matter content. Since $\mathrm{SO}_{4}^{2-}$ is readily leached from the soil there is no point in attempting to raise soil $\mathrm{S}$ levels by excessive fertilization. Furthermore, on livestock farms, excess $S$ may depress the uptake of selenium in herbage and interfere with the absorption of copper by animals (Till 2002). Walker $\&$ Dawson (2002) reviewed the $S$ fertilizer recommendations in Europe and found that most advisory bodies across Europe adopted an empirical system of advisory level of $S$ required based on potential yield of crop, soil type and farming system.

To maintain a sufficient $S$ supply in the future, when further reductions in the atmospheric deposition may be expected, it is important to reduce the leaching losses of $\mathrm{SO}_{4}^{2-}$. Catch crops, especially cruciferous crops that have a high $\mathrm{S}$ demand and vigorous root growth, can do this effectively (Eriksen \& Thorup-Kristensen 2002). In a crop rotation including both low S-demanding cereals and high S-demanding main crops (e.g. crucifers or vegetables), a suitable catch crop strategy may prevent excess $\mathrm{SO}_{4}^{2-}$ from leaching in years when low S-demanding crops are grown, and instead transfer $S$ to the following high $S$-demanding crop. This is most important in low input systems, for example organic farming, but also of relevance to other farming systems. For such a strategy to work it is important that $\mathrm{S}$ immobilized in the catch crop is mineralized rapidly after incorporation. However, mineralization rates depend much on the choice of catch crop. The highest rates have been found for cruciferous crops and the lowest ones for legumes (Eriksen \& Thorup-Kristensen 2003). Differences were partly explained by the $\mathrm{C} / \mathrm{S}$ ratio of the decomposing plant material. It is generally claimed that $\mathrm{SO}_{4}^{2-}$ is mineralized from organic material when the $\mathrm{C} / \mathrm{S}$ ratio is less than 200 and is immobilized if the C/S ratio is above 400 , whereas C/S ratios between 200 and 400 may cause either net mineralization or net immobilization (Barrow 1960). This rule seems to apply across different organic materials such as sludge, animal manure and plant material (Tabatabai \& Chae 1991; Musvoto et al. 2000; Reddy et al. 2002; Eriksen \& Thorup-Kristensen 2003). Thus, it is always advisable to use supplemental $S$ fertilizers during the incorporation of strongly immobilizing materials.

\section{Equitable re-distribution of nutrients from manure}

Intensive livestock farming usually requires purchase of supplementary feedstuff, and this represents an input to the farm which, following utilization by animals, results in a surplus of nutrients, including $\mathrm{N}$ and $\mathrm{S}$. There are regulations aimed at minimizing nutrient accumulation in soils on animal farms, allowing a maximum animal density per unit of arable land (Sweden) or a maximum nutrient application through animal wastes per unit of land (Denmark). Nevertheless, it is almost impossible, using current manure management practices, to ensure that nutrients are equitably re-distributed. Thus the nutrient budgets of intensive livestock farms are generally imbalanced. Currently, due to the high water and relatively low nutrient contents in animal manures as compared to concentrated inorganic fertilizers, transport of these waste products is economically and practically feasible over only short distances. Furthermore, application of animal manures to soil requires more energy than harvesting operations. Economic studies indicate that the fertilizer value of solid cattle manure covers the cost of transportation only up to a distance of about 15 kilometers, and even shorter distances for slurries (Greaves et al. 1999).

It has been suggested that the widespread establishment of self-sustaining, mixed organic farms across regions might lead to more uniform re-distribution of nutrients present in manures, although the economic and environmental implications of such changes have not been considered. Another view is that the problem of imbalanced re-distribution of nutrients present in animal manures could be overcome, not through a restructuring of agricultural production, but by improvements in the processing of the large quantities of wastes generated by intensive livestock enterprises, so as to allow for more equitable re-distribution of the nutrients they contain.

Development of new technologies to extract nutrients out of organic wastes may provide a solution to the imbalanced re-distribution to agricultural soils. For example, one method for recovery of $\mathrm{N}$ and $\mathrm{P}$ from manures (Schuiling \& Andrade 1999) is based on precipitation as struvite (magnesium ammonium phosphate). Recovery of nutrients in water-soluble forms from animal wastes would be the most desired agronomic option, providing farmers with efficient fertilizers. An optimal concept might be a centralized regional plant producing biogas from animal wastes brought from livestock farms, and including nutrient extraction and production of inorganic fertilizer compounds.

\section{SUMMARY AND CONCLUSION}

Clearly, several common critical factors need to be considered for efficient management of $\mathrm{N}$ and $\mathrm{S}$ in agricultural systems, especially for those with an emphasis on organic nutrient sources. Leaching losses of $\mathrm{N}$ and $\mathrm{S}$, induced by additions of high quality plant residues with low $\mathrm{C} / \mathrm{N}$ or $\mathrm{C} / \mathrm{S}$ ratios (e.g. leguminous or cruciferous green manures) as well as large quantities of animal manures, are of major concern. Besides potentially large leaching loads, substantial emissions of $\mathrm{N}$ as ammonia are also associated with land-spreading of manures, whereas volatile losses of $\mathrm{S}$ have been much less well characterized. Large inputs of manure also increase the $\mathrm{C}$ content in soil and consequently enhance the potential for further losses of $\mathrm{N}$ via denitrification. Other volatile losses of $\mathrm{N}$ and $\mathrm{S}$ can occur during the manure handling chain, although management guidelines for storage of manures in intensive enterprises in Europe and the USA are currently well developed.

There is no doubt that organic materials represent a major nutrient input to many farming systems, particularly in the case of $\mathrm{N}$ from legumes and both $\mathrm{N}$ and $\mathrm{S}$ in manures. However, efficient use of the inputs is often hampered by asynchrony between plant-available release from the organic source and crop demand, primarily driven by the quantity and quality of the input. Although there are 
currently some options for managing these organic inputs of $\mathrm{N}$ and $\mathrm{S}$, such as minimizing tillage, optimizing timing of manure applications and using cover or catch crops, it is critical that further innovative research is undertaken, aimed at improving the efficiency of $\mathrm{N}$ and $\mathrm{S}$ cycling in all farming systems. Approaches may include:

- selection of appropriate crop and pasture species/mixtures;

- addition of on- and off-farm wastes to manipulate soil $\mathrm{N}$ and S supply;

- altering the cycling of $\mathrm{N}$ and $\mathrm{S}$ via animal excreta by changing animal diets;

- developing new strategies, such as nutrient extraction from animal wastes and use of feed pad systems, to redistribute outputs from grazing animals.

\section{ACKNOWLEDGEMENTS}

The corresponding author thanks Sigrun Dahlin and an anonymous reviewer for very useful comments on the manuscript. Food 21 Program provided welcome financial assistance for several of the authors to attend two workshops concerned with the development of this manuscript.

\section{REFERENCES}

Aaes O \& Thøgersen R 1999. Sulphur to cattle. LK-note 427. The Danish Advisory Centre Skejby Denmark. [In Danish]

Anderson GC Fillery IRP Dolling P \& Asseng S 1998a. Nitrogen and water flows under pasture-wheat and lupin-wheat rotations in deep sands in Western Australia 1. Nitrogen fixation in legumes, net $\mathrm{N}$ mineralisation, and utilisation of soil-derived nitrogen. Australian Journal of Agricultural Research 49, 329-343.

Anderson GC Fillery IRP Dunin FX Dolling PJ \& Asseng S 1998 b. Nitrogen and water flows under pasture-wheat and lupin-wheat rotations in deep sands in Western Australia 2. Drainage and nitrate leaching. Australian Journal of Agricultural Research 49, 345-361.

Arah JRM Smith KA Crichton IJ \& Li HS 1991. Nitrous oxide production and denitrification in Scottish arable soils. Journal of Soil Science 42, 351-367.

Armstrong EL Heenan DP Pate JS \& Unkovich MJ 1997. Nitrogen benefits of lupins, field pea, and chickpea to wheat production in south-eastern Australia. Australian Journal of Agricultural Research 48, 39-47.

Aronsson H 2000. Nitrogen turnover and leaching in cropping systems with ryegrass catch crops. Acta Universitatis Agriculturae Sueciae Agraria PhD Thesis Swedish University of Agricultural Sciences Uppsala.

Badaruddin M \& Meyer DW 1994. Grain legume effects on soil nitrogen, grain yield, and nitrogen nutrition of wheat. Crop Science 34, 1304-1309.

Baggs EM Rees RM Smith KA \& Vinten AJA 2000. Nitrous oxide emissions from soils after incorporating crop residues. Soil Use and Management 16, 82-87.

Ball RP \& Ryden JC 1984. Nitrogen relationships in intensively managed temperate grasslands. Plant and Soil 76, 23-33.

Banwart WL \& Bremner JM 1975. Identification of sulfur gases evolved from animal manures. Journal of Environmental Quality 4, 363-366.

Barrow NJ 1960. A comparison of the mineralization of nitrogen and of sulfur from decomposing organic materials. Australian Journal of Agricultural Research 11, 960-969.

Beard WE \& Guenzi WD 1983. Volatile sulfur compounds from a redoxcontrolled cattle-manure slurry. Journal of Environmental Quality 12, $113-116$.
Beck DP Wery J Saxena MC \& Ayadi A 1991. Dinitrogen fixation and nitrogen balance in cool-season food legumes. Agronomy Journal 83, 334-341.

Beckwith CP Cooper J Smith KA \& Shepherd MA 1998. Nitrogen leaching loss following application of organic manures to sandy soils in arable cropping. Soil Use and Management 14, 123-130.

Bergström L \& Brink N 1986. Effects of differentiated applications of fertilizer $\mathrm{N}$ on leaching and distribution of $\mathrm{N}$ in the soil. Plant and Soil 93, 333-345.

Bergström LF \& Jokela WF 2001. Ryegrass cover crop effects on nitrate leaching in spring barley fertilized with ${ }^{15} \mathrm{NH}_{4}{ }^{15} \mathrm{NO}_{3}$. Journal of Environmental Quality 30, 1659-1667.

Bergström LF \& Kirchmann H 1999. Leaching of total nitrogen from nitrogen-15-labeled poultry manure and inorganic nitrogen fertilizer. Journal of Environmental Quality 28, 1283-1290.

Bijay-Singh Ryden JC \& Whitehead JC 1988. Some relationships between denitrification potential and fractions of organic carbon in air-dried and field-moist soils. Soil Biology and Biochemistry 20, 737-741.

Blair GJ 2002. Sulphur fertilisers: A global perspective. Proceedings No. 498, International Fertiliser Society York UK 36 pp.

Boller BC \& Nösberger J 1987. Symbiotically fixed nitrogen from fieldgrown white and red clover mixed with ryegrass at low levels of ${ }^{15} \mathrm{~N}$ fertilization. Plant and Soil 104, 219-226.

Brown KA 1982. Sulphur in the environment: a review. Environmental Pollution series B 3, 47-80.

Bussink DW \& Oenema O 1998. Ammonia volatilization from dairy farming systems in temperate areas: a review. Nutrient Cycling in Agroecosystems $51,19-33$.

Chalk PM 1991. The contribution of associative and symbiotic nitrogen fixation to the nitrogen nutrition of non-legumes. Plant and Soil 132, $29-39$.

Chambers BJ Smith KA \& van der Weerden TJ 1997. Ammonia emissions following the land spreading of solid manures. In: Gaseous nitrogen emissions from grasslands, eds SC Jarvis \& BF Pain, CAB International Wallingford UK pp 275-280.

Chao TT Harward ME \& Fang SC 1962. Adsorption and desorption phenomena of sulfate ions in soils. Soil Science Society of America Proceedings 26, 234-237.

Cowell LE Bremer E \& Van Kessel C 1989. Yield and nitrogen fixation of pea and lentil as affected by intercropping and $\mathrm{N}$ application. Canadian Journal of Soil Science 69, 243-251.

Curtin D \& Syers JK 1990. Extractability and adsorption of sulphate in soils. Journal of Soil Science 41, 295-304.

Cuttle SP Scurlock RV \& Davies BMS 1998. A 6 year comparison of nitrate leaching from grass/clover and N-fertilized grass pastures grazed by sheep. Journal of Agricultural Science Cambridge 131, 39-50.

Danso SKA Zapata F Hardarson G \& Fried M 1987. Nitrogen fixation in fababeans as affected by plant population density in sole or intercropped systems with barley. Soil Biology and Biochemistry 19, 411-415.

Dentener GJ \& Crutzen PJ 1994. A three-dimensional model of the global ammonia cycle. Journal of Atmospheric Chemistry 19, 331-369.

De Neve S Gaona Saez S Chaves Daguilar B Sleutel S \& Hofman G 2004. Manipulating $N$ mineralization from high $N$ crop residues using on- and off-farm organic materials. Soil Biology and Biochemistry 36, $127-134$.

ECETOC 1994. Ammonia emissions to air in Western Europe. Technical Report 62. European Centre for Ecotoxicology and Toxicology of Chemicals Brussels Belgium 195 pp.

Eriksen J 1996. Incorporation of S into soil organic matter in the field as determined by the natural abundance of stable $S$ isotopes. Biology and Fertility of Soils 22, 149-155.

Eriksen J 2002. Organic manures as sources of fertiliser sulphur. Proceedings No. 505, International Fertiliser Society York UK 20 pp.

Eriksen J \& Askegaard M 2000. Sulphate leaching in an organic crop rotation on sandy soil in Denmark. Agriculture, Ecosystems and Environment 78, 107-114.

Eriksen J Mortensen J Kjellerup VK \& Kristjansen O 1995. Forms and plant availability of sulfur in cattle and pig slurry. Zeitschrift für Pflanzenernährung und Bodenkunde 158, 113-116.

Eriksen J Murphy M \& Schnug E 1998. The soil sulphur cycle. In: Sulphur in agroecosystems, ed E Schnug. Nutrients in Ecosystems. Kluwer Academic Publishers Dordrecht Netherlands pp 39-73. 
Eriksen J \& Thorup-Kristensen K 2002. The effect of catch crops on sulphate leaching and availibility of $S$ in the succeeding crop on sandy loam soil in Denmark. Agriculture, Ecosystems and Environment 90, $247-254$.

Eriksen J \& Thorup-Kristensen K 2003. The effect of catch crops on sulphate leaching and availability of $S$ in the succeeding crop. In: Sulfur transport and assimilation in plants. Regulation, interaction and signaling, eds JC Davidian D Grill LJ De Kok H Stulen MJ Hawkesford E Schnug \& H Rennenberg, Backhuys Publishers Leiden pp 205-207.

Farwell SO Sherrard AE Pack ME \& Adams DF 1979. Sulfur compounds volatilised from soils at different moisture contents. Soil Biology and Biochemistry 11, 411-415.

Ferm M 1998. Atmospheric ammonia and ammonium transport in Europe and critical loads: a review. Nutrient Cycling in Agroecosystems 51, 5-17.

Fillery IRP 2001. The fate of biologically fixed nitrogen in legume-based dryland farming systems: a review. Australian Journal of Experimental Agriculture 41, 361-381.

Foulkes MJ Sylvester-Bradley R \& Scott RK 1998. Evidence for differences between winter wheat cultivars in acquisition of soil mineral nitrogen and uptake and utilisation of applied fertiliser nitrogen. Journal of Agricultural Science Cambridge 130, 29-44.

Freney JR 1986. Forms and reactions of organic sulfur compounds in soil. In: Sulfur in agriculture, ed MA Tabatabai, American Society of Agronomy Madison WI pp 207-232.

Fujita K Ofusu-Budu KG \& Ogata S 1992. Biological nitrogen fixation in mixed legume-cereal cropping systems. Plant and Soil 141, 155-175.

Giller KE Cadisch G Ehaliotis C Adams ER Sakala WD \& Mafongoya PL 1997. Building soil nitrogen capital in Africa. In: Replenishing soil fertility in Africa, eds RJ Buresh PA Sanchez \& F Calhoun, Soil Science Society of America Madison WI pp 151-192.

Granstedt A 1995. Studies of the flow, supply and losses of nitrogen and other plant nutrients in conventional and ecological agricultural systems in Sweden. Biological Agriculture and Horticulture 11, 51-67.

Greaves J Hobbs P Chadwick D \& Haygarth P 1999. Prospects for the recovery of phosphorus from animal manures: a review. Environmental Technology 20, 697-708.

Gunnarsson S \& Marstorp H 2002. Carbohydrate composition of plant materials determines $\mathrm{N}$ mineralisation. Nutrient Cycling in Agroecosystems $62,175-183$.

Gustavsson J 1998. Swedish measures to reduce ammonia emissions. Nutrient Cycling in Agroecosystems 51, 81-83.

Handayanto E Cadisch G \& Giller KE 1997. Regulating N mineralisation from plant residues by manipulation of quality. In: Driven by Nature: plant litter quality and decomposition, eds G Cadisch \& KE Giller, CAB International Wallingford UK pp 175-185.

Harward ME \& Reisenauer HM 1966. Reactions and movement of inorganic soil sulfur. Soil Science 101, 326-335.

Hauck RD 1986. Field measurement of denitrification - an overview. In: Field measurement of dinitrogen fixation and denitrification, eds RD Hauck \& RW Weaver. Special Publication No. 18. Soil Science Society of America Madison WI pp 59-72.

Haynes RJ \& Williams PH 1993. Nutrient cycling and soil fertility in the grazed pasture ecosystem. Advances in Agronomy 49, 119-199.

Heger J Mengesha S Blaha J \& Koch F 1997. Estimation of minimum crude protein levels in diets for high-lean growth pigs. Agribiological Research 50, 64-77.

Hilhorst GJ Oenema J \& van Keulen H 2001. Nitrogen management on experimental dairy farm 'De Marke'; farming system, objectives and results. Netherlands Journal of Agricultural Science 49, 135-151.

Høgh-Jensen H \& Schjoerring JK 2001. Rhizodeposition of nitrogen by red clover, white clover and ryegrass leys. Soil Biology and Biochemistry $33,439-448$.

Hossain SA Dalal RC Waring SA Strong WM \& Weston EJ 1996. Comparison of legume-based cropping systems at Warra, Queensland. I. Soil nitrogen and organic carbon accretion and potentially mineralisable nitrogen. Australian Journal of Soil Research 34, 273-287.

Huijsmans JFM Hol JMG \& Bussink DW 1997. Reduction of ammonia emission by new slurry application techniques on grassland. In: Gaseous nitrogen emissions from grasslands, eds SC Jarvis \& BF Pain, CAB International Wallingford UK pp 281-285.

Huijsmans JFM Hol JMG \& Hendriks MMW 2001. Effect of application technique, manure characteristics, weather and field conditions on ammonia volatilization from manure applied to grassland. Netherlands Journal of Agricultural Science 49, 323-342.

Izaurralde RC McGill WB \& Juma NG 1992. Nitrogen fixation efficiency, interspecies $\mathrm{N}$ transfer and root growth in barley-field pea intercrop on Black Chernozemic soil. Biology and Fertility of Soils 13, 11-16.

Janzen HH \& Ellert BH 1998. Sulfur dynamics in cultivated temperate agroecosystems. In: Sulfur in the environment, ed DG Maynard, Marcel Dekker Inc. New York pp 11-43.

Jarvis SC \& Pain B 1990. Ammonia volatilization from agricultural land. Proceedings No. 298. The Fertiliser Society London.

Jenkinson DS 1990. The turnover of organic carbon and nitrogen in soil. Philosophical Transactions of the Royal Society of London Series B, Biological Sciences 329, 361-368.

Jensen ES 1996a. Rhizodeposition of $\mathrm{N}$ by pea and barley and its effect on soil N dynamics. Soil Biology and Biochemistry 28, 65-71.

Jensen ES 1996b. Barley uptake of $\mathrm{N}$ deposited in the rhizosphere of associated field pea. Soil Biology and Biochemistry 28, 159-168.

Jensen ES 1996c. Grain yield, symbiotic $\mathrm{N}_{2}$ fixation and interspecific competition for inorganic $\mathrm{N}$ in pea-barley intercrops. Plant and Soil 182, 25-38.

Jensen ES 1997. The role of grain legume nitrogen fixation in the nitrogen cycling of temperate cropping systems. Risø National Laboratory Roskilde Denmark.

Jørgensen FV \& Ledgard SF 1997. Contribution from stolons and roots to estimated of the total amount of $\mathrm{N}_{2}$ fixed by white clover (Trifolium repens L.). Annals of Botany 80, 641-648.

Kemppainen E 1995. Leaching and uptake of nitrogen and phosphorus from cow slurry and fox manure in a lysimeter trial. Agricultural Sciences Finland 4, 363-375.

Kennedy IR \& Islam N 2001. The current and potential contribution of asymbiotic nitrogen fixation to nitrogen requirements on farms: a review. Australian Journal of Experimental Agriculture 41, 447-457.

Khan DF Peoples MB Schwenke GD Felton WL Chen D \& Herridge DF 2003. Effects of below-ground nitrogen on $\mathrm{N}$ balances of field-grown fababean, chickpea and barley. Australian Journal of Agricultural Research 54, 333-340.

Kirchmann H 1985. Losses, plant uptake and utilisation of manure nitrogen during a production cycle. Acta Agriculturae Scandinavica, Supplementum 24. PhD Dissertation Swedish University of Agricultural Sciences Uppsala.

Kirchmann H 1989. A 3-year study with aerobic, anaerobic and fresh ${ }^{15} \mathrm{~N}$ labelled poultry manure. In: Nitrogen in organic wastes applied to soils, eds JA Hansen \& K Henriksen, Academic Press London pp 113-125.

Kirchmann H \& Bergström L 2003. Use of paper-mill waste on agricultural soils: is this a way to reduce nitrate leaching. Acta Agriculturae Scandinavica 53, 56-63.

Kirchmann H \& Lundvall A 1993. Relationship between N immobilization and volatile fatty acids decomposition in soil after application of cattle and pig slurry. Biology and Fertility of Soils 15, 161-164.

Kirchmann H \& Lundvall A 1998. Treatment of solid animal manures: identification of low $\mathrm{NH}_{3}$ emission practices. Nutrient Cycling in Agroecosystems 51, 65-71.

Kirchmann H Pichlmayer F \& Gerzabek MH 1996. Sulfur balances and sulfur-34 abundances in a long-term fertilizer experiment. Soil Science Society of America Journal 59, 174-178.

Kirchmann H \& Witter E 1989. Ammonia volatilization during aerobic and anaerobic manure decomposition. Plant and Soil 115, 35-41.

Kirchmann H \& Witter E 1992. Composition of fresh, aerobic and anaerobic farm animal dungs. Bioresource Technology 40, 137-142.

Knights JS Zhao FJ Spiro B \& McGrath SP 2000. Long-term effects of land use and fertiliser treatments on sulfur cycling. Journal of Environmental Quality 29, 1867-1874.

Kumar K \& Goh KM 2000. Crop residues and management practices: effects on soil quality, soil nitrogen dynamics, crop yield, and nitrogen recovery. Advances in Agronomy 68, 236-279.

Kyvsgaard P Sörensen P Möller E \& Magid J 2000. Nitrogen mineralization from sheep faeces can be predicted from the apparent digestibility of the feed. Nutrient Cycling in Agroecosystems 57, 207-214.

Le Gouis J Beghin J Heamez E \& Pluckard P 2000. Genetic differences for $\mathrm{N}$ uptake and utilisation efficiencies in winter wheat. European Journal of Agronomy 12, 163-173.

Ledgard SF 2001. Nitrogen cycling in low input legume-based agriculture, with emphasis on legume/grass pastures. Plant and Soil 228, 43-59. 
Ledgard SF Penno JW \& Sprosen MS 1999. Nitrogen inputs and losses from clover/grass pastures grazed by dairy cows, as affected by nitrogen fertiliser application. Journal of Agricultural Science Cambridge 132, $215-225$.

Ledgard SF \& Steele KW 1992. Biological nitrogen fixation in mixed legume/grass pastures. Plant and Soil 141, 137-153.

Lewan E 1994. Effects of a catch crop on leaching of nitrogen from a sandy soil: simulations and measurements. Plant and Soil 166, 137-152.

Lloyd A 1994. Effectiveness of cattle slurry as a sulphur source for grass cut for silage. Grass and Forage Science 49, 203-208.

Lord EI \& Mitchell RDJ 1998. Effect of nitrogen inputs to cereals on nitrogen leaching from sandy soils. Soil Use and Management 14, $78-83$.

Lorenz F \& Steffens G 1997. Effect of application techniques on ammonia losses and herbage yield following slurry application to grassland. In: Gaseous nitrogen emissions from grasslands, eds SC Jarvis \& BF Pain, CAB International Wallingford UK pp 287-292.

Martinez J \& Guiraud G 1990. A lysimeter study of the effects of a ryegrass catch crop, during a winter wheat/maize rotation, on nitrate leaching and on the following crop. Journal of Soil Science 41, 5-16.

Mayer J Buegger F Steen Jensen E Schloter M \& Hess J 2003. Estimating $\mathrm{N}$ rhizodeposition of grain legumes using a ${ }^{15} \mathrm{~N}$ in situ stem labelling method. Soil Biology and Biochemistry 35, 21-28.

McGrath SP Zhao FJ \& Blake-Kalff MMA 2002. History and outlook for sulphur fertilisers in Europe. Proceedings No. 497. International Fertiliser Society York UK 24 pp.

McNeill AM Zhu C \& Fillery IR 1997. Use of in situ ${ }^{15} \mathrm{~N}$ labelling to estimate the total below-ground nitrogen of pasture legumes in intact soilplant systems. Australian Journal of Agricultural Research 48, 295-304.

Meisinger JJ Hargrove WL Mikkelsen RL Williams JR \& Benson VW 1991. Effects of cover crops on groundwater quality. In: Cover crops for clean water, ed WL Hargrove, Soil and Water Conservation Society Ankeny IA pp 57-68.

Menzi H Katz P Frick P Fahrni M \& Keller M 1997. Ammonia emissions following the application of solid manure to grassland. In: Gaseous nitrogen emissions from grasslands, eds SC Jarvis \& BF Pain, CAB International Wallingford UK pp 265-274.

Metson AJ 1979. Sulphur in New Zealand soils 1. New Zealand Journal of Agricultural Research 22, 95-114.

Misselbrook TH Van der Weerden TJ Pain BF Jarvis SC Chambers BJ Smith KA Phillips VR \& Demmers TGM 2000. Ammonia emission factors for UK agriculture. Atmospheric Environment 34, 871-880.

Musvoto C Campbell BM \& Kirchmann H 2000. Decomposition and nutrient release from mango and miombo woodland litter in Zimbabwe. Soil Biology and Biochemistry 32, 1111-1119.

Myers RJK Palm CA Cuevas E Gunatilleke IUN \& Brossard M 1994. The synchronisation of mineralisation and plant nutrient demand. In: The biological management of tropical soil fertility, eds PL Woomer \& MJ Swift, John Wiley \& Sons Chichester UK pp 81-116.

Myers RJK Van Noordwijk M \& Vityakon P 1997. Synchrony of Nutrient Release and Plant Demand: Plant Litter Quality, Soil Environment and Farmer Management Options. In: Driven by Nature: plant litter quality and decomposition, eds $\mathrm{G}$ Cadisch \& $\mathrm{K}$ Giller, CAB International Wallingford UK pp 215-229.

National Research Council 1989. Alternative agriculture. National Academy Press Washington DC.

Nieder R Schollmeyer G \& Richter J 1989. Denitrification in the rooting zone of cropped soils with regard to methodology and climate: a review. Biology and Fertility of Soils 8, 219-226.

NILU 2003. Available: http://www.nilu.no/projects/ccc/emepdata.html [November 2003]. Norwegian Institute for Air Research.

Nygaard Sørensen J 1991. Effect of catch crops on the content of soil mineral nitrogen before and after winter leaching. Zeitschrift für Pflanzenernährung und Bodenkunde 155, 61-66.

Pain BF \& Misselbrook TH 1997. Sources of variation in ammonia emission factors for manure applications to grassland. In: Gaseous nitrogen emissions from grasslands, eds SC Jarvis \& BF Pain, CAB International Wallingford UK pp 293-301.

Papastylianou I 1988. The ${ }^{15} \mathrm{~N}$ methodology in estimating $\mathrm{N}_{2}$ fixation by vetch and pea grown in pure stand or in mixes with oat. Plant and Soil 107, 183-188.

Papastylianou I 1999. Estimation of nitrogen fixed by legumes in longterm vs short-term cropping systems. Agronomy Journal 91, 329-334.
Parton WJ Woomer PL \& Martin A 1994. Modelling soil organic matter dynamics and plant productivity in tropical ecosystems. In: The biological management of tropical soil fertility, eds PL Woomer \& MJ Swift, Wiley-Sayce New York pp 171-188.

Paynel F Murray PJ \& Cliquet JB 2001. Root exudates: a pathway for short-term N transfer from clover and ryegrass. Plant and Soil 229, $235-243$.

Peoples MB \& Baldock JA 2001. Nitrogen dynamics of pastures: nitrogen fixation inputs, the impact of legumes on soil nitrogen fertility, and the contributions of fixed nitrogen to Australian farming systems. Australian Journal of Experimental Agriculture 41, 327-346.

Peoples MB Herridge DF \& Ladha JK 1995. Biological nitrogen fixation: an efficient source of nitrogen for sustainable agricultural production? Plant and Soil 174, 3-28.

Rahn CR Bending GD Turner MK \& Lillywhite RD 2003. Management of $\mathrm{N}$ mineralisation from crop residues of high $\mathrm{N}$ content using amendment materials of varying quality. Soil Use and Management 19, 193-200.

Reddy KS Singh M Swarup A Rao AS \& Sing KN 2002. Sulfur mineralisation in two soils amended with organic manures, crop residues, and green manures. Journal of Plant Nutrition and Soil Science 165, $167-171$.

Ridley AM White RE Helyar KA Morrison GR Heng LK \& Fisher R 2001. Nitrate leaching loss under annual and perennial pastures with and without lime on a duplex (texture contrast) soil in humid southeastern Australia. European Journal of Soil Science 52, 237-252.

Rochester IJ Peoples MB Constable GA \& Gault RR 1998. Faba beans and other legumes add nitrogen to irrigated cotton cropping systems. Australian Journal of Experimental Agriculture 38, 253-260.

Russell CA \& Fillery IRP 1996. Estimates of lupin below-ground biomass nitrogen, dry matter, and nitrogen turnover to wheat. Australian Journal of Agricultural Research 47, 1047-1059.

Ruz-Jerez BE White RE \& Ball PR 1995. A comparion of nitrate leaching under clover-based pastures and nitrogen-fertilized grass grazed by sheep. Journal of Agricultural Science Cambridge 125, 361-369.

Sawatsky N \& Soper RJ 1991. A quantitative measurement of the nitrogen loss from the root system of field peas (Pisum avense L.) grown in the soil. Soil Biology and Biochemistry 23, 255-259.

Scherer HW 2001. Sulphur in crop production. European Journal of Agronomy $14,81-111$.

Schuiling RD \& Andrade A 1999. Recovery of struvite from calf manure. Environmental Technology 20, 765-768.

Schwenke GD Peoples MB Turner GL \& Herridge DF 1998. Does nitrogen fixation of commercial, dryland chickpea and faba bean crops in north-west New South Wales maintain or enhance soil nitrogen? Australian Journal of Experimental Agriculture 38, 61-70.

Shepherd MA 1999. The effectiveness of cover crops during eight years of a UK sandland rotation. Soil Use and Management 15, 41-48.

Shepherd MA \& Bennett G 1998. Nutrient leaching losses from a sandy soil in lysimeters. Communications in Soil Science and Plant Analysis 29, 931-946.

Smith KA \& Chambers BJ 1995. Muck: from waste to resource. Utilisation: the impacts and implications. Proceedings of the MUCK '95 Conference. Agricultural Engineer, Summer 1995.

Sommer SG \& Olesen JE 1991. Effects of dry matter content and temperature on ammonia loss from surface applied cattle slurry. Journal of Environmental Quality 20,679-683.

Soussana JF \& Hartwig UA 1996. The effect of elevated $\mathrm{CO}_{2}$ on symbiotic $\mathrm{N}_{2}$ fixation: a link between carbon and nitrogen cycles in grassland ecosystems. Plant and Soil 187, 321-332.

Steineck S Gustafson G Andersson A Tersmeden M \& Bergström J 1999. Stallgödselns innehåll av växtnäring och spårelement. Swedish Environmental Protection Agency, Report 4974, Stockholm Sweden.

Stockdale EA Lampkin NH Hovi M Keatinge R Lennartsson EKM MacDonald DW Padel S Tattersall FH Wolfe MS \& Watson CA 2001. Agronomic and environmental implications of organic farming systems. Advances in Agronomy 70, 261-327.

Stopes C Lord EI Phillips L \& Woodward L 2002. Nitrate leaching from organic farms and conventional farms following best practice. Soil Use and Management 18, 256-263.

Tabatabai MA \& Chae YM 1991. Mineralization of sulfur in soils amended with organic wastes. Journal of Environmental Quality 20, 684-690. 
Thomsen IK Hansen JF Kjellerup V \& Christensen BT 1997. Effects of cropping system and rates of nitrogen in animal slurry and mineral fertilizer on nitrate leaching from a sandy loam. Soil Use and Management $9,53-58$.

Till R 2002. Sulphur fertilisers, forage quality and animal production. Proceedings No. 501. International Fertiliser Society York UK 27 pp.

Ulyatt MJ Thomson DJ Beever DE Evans RT \& Haines M 1988. The digestion of perennial ryegrass (Lolium perenne cv Melle) and white clover (Trifolium repens cv Blanca) by grazing cattle. British Journal of Nutrition 60, 137-149.

Unkovich MJ \& Pate JS 2000. An appraisal of recent field measurements of symbiotic $\mathrm{N}_{2}$ fixation by annual legumes. Field Crops Research 65, 211-228.

Unkovich MJ Pate JS \& Sanford P 1997. Nitrogen fixation by annual legumes in Australian Mediterranean agriculture. Australian Journal of Agricultural Research 48, 267-293.

Van Kessel C \& Hartley C 2000. Agricultural management of grain legumes: has it led to an increase in nitrogen fixation? Field Crops Research 65, 165-181.

Velthof GL Kuikman PJ \& Oenema O 2002. Nitrous oxide emission from soils amended with crop residues. Nutrient Cycling in Agroecosystems 62, 249-261.

Vinten AJA Castle K \& Arah JRM 1996. Field evaluation of models of denitrification linked to nitrate leaching for aggregated soil. European Journal of Soil Science 47, 305-317.

Vinther FP \& Jensen ES 2000. Estimating legume $\mathrm{N}_{2}$ fixation in grass-clover mixtures of a grazed organic cropping system using two N-15 methods. Agriculture Ecosystems and Environment 78, $139-147$.
Watson CA Atkinson D Gosling P Jackson LR \& Rayns FW 2002. Managing soil fertility in organic farming systems. Soil Use and Management $18,239-247$.

Walker K \& Dawson C 2002. Sulphur fertiliser recommendations in Europe. Proceedings No. 504. International Fertiliser Society York UK $12 \mathrm{pp}$.

Waterer JG Vessey JK Stobbe EH \& Soper RJ 1994. Yield and symbiotic nitrogen fixation in a pea-mustard intercrop as influenced by $\mathrm{N}$ fertiliser additions. Soil Biology and Biochemistry 26, 447-453.

Webster CP \& Goulding KWT 1989. Influence of soil carbon content on denitrification from fallow land during autumn. Journal of the Science of Food and Agriculture 49, 131-142.

Weier KL Doran JW Power JF \& Walters DT 1993. Denitrification and the dinitrogen/nitrous oxide ratio as affected by soil water, available carbon, and nitrate. Soil Science Society of America Journal 57, 66-72.

White PF Nersoyan NK \& Christiansen S 1994. Nitrogen cycling in a semi-arid Mediterranean region: changes in soil $\mathrm{N}$ and organic matter under several crop/livestock production systems. Australian Journal of Agricultural Research 45, 1293-1307.

Whitehead DC 2000. Nutrient elements in grassland: soil-plant-animal relationships. CAB International Wallingford UK.

Yan X Akimoto H \& O'Hara T 2003. Estimation of nitrous oxide, nitric oxide and ammonia emissions from croplands in East, Southeast and South Asia. Global Change Biology 9, 1080-1096.

Zhao FJ McGrath SP Blake-Kalff MMA Link A \& Tucker M 2002 Crop responses to sulphur fertilisation in Europe. Proceedings No. 504, International Fertiliser Society York UK 27 pp. 